JP3I (Jurnal Pengukuran Psikologi dan Pendidikan Indonesia), I0(2), 202I, I58-I7I

D0l: http://dx.doi.org/I0.15408/jp3i.v10i2.21618

http://journal.uinjkt.ac.id/index.php/jp3i

\title{
Adaptation and Assessment of Psychometric Properties of the Brief Sensation-seeking Scale in an Indonesian General Sample
}

\author{
Sunu Bagaskara \\ Faculty of Psychology, Universitas YARSI, Indonesia \\ sunu.bagaskara@yarsi.ac.id
}

\begin{abstract}
This study aimed to examine the psychometric properties of the Brief Sensation-seeking Scale (BSSS, Hoyle et al., 2002) in an Indonesian sample. A set of questionnaires consisting of an adaptation of the BSSS, Ten Item Personality Inventory (TIPI)-Indonesia, and a risky driving behavior scale were administered to 360 participants with an average age of 25.23 years. The reliability test using the internal consistency method showed high reliability $(\alpha=0.79)$. CFA analysis shows that the factor structure of the 4 -factor BSSS-Indonesia model is more fit to the data than the 1-factor model. Construct validity was also found from the results of the correlation analysis of the BSSS-I score with the personality traits of openness to experience (convergent), agreeableness, and conscientiousness (discriminant). Regarding demographics, it was found that there were differences in the average scores between both sexes and age groups. The BSSS-I score was also found to be a significant predictor of risky driving behavior (concurrent validity). Taken together, the findings of this study show satisfactory evidence of psychometric properties, in line with previous adaptation of BSSS in several other cultures. This indicates that the BSSS-I is a sound instrument to measure trait sensation-seeking in the Indonesian population.
\end{abstract}

Keywords: brief sensation-seeking scale, CFA, reliability, validity.

\begin{abstract}
Abstrak
Studi ini bertujuan untuk menguji properti psikometris dari Brief Sensation-seeking Scale (BSSS, Hoyle dkk., 2002) pada sampel Indonesia. Satu set kuesioner yang terdiri dari adaptasi BSSS, Ten Item Personality Inventory (TIPI)Indonesia, dan skala perilaku mengemudi berisiko diberikan kepada 360 partisipan dengan rata-rata usia 25,23 tahun. Pengujian reliabilitas dengan metode konsistensi internal menunjukkan reliabilitas yang tinggi $(\alpha=0,79)$. Analisis CFA menunjukkan bahwa struktur faktor BSSS-Indonesia model 4-faktor lebih fit dengan data dibandingkan dengan model 1-faktor. Validitas konstruk juga ditemukan dari hasil analisis korelasi skor BSSS-I dengan trait kepribadian openness to experience (konvergen), agreeableness, dan conscientiousness (diskriminan). Dalam hal demografi, ditemukan adanya perbedaan rata-rata skor antar jenis kelamin dan juga kelompok usia. Skor BSSS-I juga ditemukan sebagai prediktor yang signifikan dari perilaku mengemudi berisiko (validitas konkuren). Dari hasil-hasil tersebut, temuan studi ini menunjukkan bukti properti psikometris yang memuaskan, seperti halnya adaptasi BSSS di beberapa budaya lainnya. Hal ini menandakan bahwa BSSS-I merupakan instrumen yang bisa diandalkan untuk mengukur trait sensation-seeking pada populasi Indonesia.
\end{abstract}

Kata Kunci: brief sensation-seeking scale, CFA, reliabilitas, validitas. 
JP3I (Jurnal Pengukuran Psikologi dan Pendidikan Indonesia), I0(2), 202 I

\section{Introduction}

The sensation-seeking construct has been widely used in various literature and has been studied from various theoretical points of view, particularly personality psychology. Zuckerman (1994) defines sensation-seeking as an individual trait characterized by a persistent desire to seek diverse, new, complex, and intense sensations and experiences, as well as a desire to take physical, social, legal, and financial risks to gain that experience. Research suggests that sensation-seeking is a personality trait that involves genetic, biological, psychophysiological, and social factors (Roberti, 2004; Zuckerman, 2009; Zuckerman \& Kuhlman, 2000).

Although sensation-seeking has a positive function in psychological well-being (Ravert et al., 2013), high levels of sensation-seeking can be strong predictors of risky behavior in various behavioral domains (Horvath \& Zuckerman, 1993; Zuckerman, 2009). Several studies found a significant positive correlation between sensation-seeking and risky premarital sexual behavior (Charnigo et al., 2013; Hald \& Mulya, 2013), marijuana consumption (Dwiputri, 2015; Pearson et al., 2018), involvement in risky sports (Baretta et al., 2017), online game addiction (Islamiah \& Supradewi, 2020; Mehroof \& Griffiths, 2010), risky driving (Bagaskara, 2017; Dahlen \& White, 2006), and cigarette consumption (Dunlop \& Romer, 2010; Hidayah \& Izzaty , 2019). These findings indicate that sensation-seeking is an important construct to measure when researching risky or maladaptive behaviors, especially in the adolescent and early adult population. In addition, understanding individual differences in sensation-seeking can be key in designing interventions to improve individuals' physical and psychosocial well-being. Therefore, it is necessary to develop valid and reliable research instruments to measure sensation-seeking constructs effectively and efficiently.

The sensation-seeking measurement that is best known and widely used is the Sensation-seeking Scale - Form V (SSS-V; Zuckerman et al., 1978). This scale consists of 40 dichotomous items which are divided into four subscales, namely: a) experience-seeking, which describes the search for sensations and experiences through thoughts and sensations (music, art, travel) and expresses a dynamic lifestyle; $b$ ) boredom susceptibility, describing the avoidance of monotonous conditions; c) thrill and adventure seeking, namely the desire to do activities full of unusual sensations (extreme activities or sports); and d) disinhibition, namely sensation-seeking based on a hedonic lifestyle (Hoyle et al., 2002; Zuckerman, 2007, 2009; Zuckerman et al., 1978).

Although SSS-V has been widely used, there are a few limitations found in its use. The three main aspects that are considered problematic are the number of items used (40 items), the dichotomous response format, and the use of outdated words and terms, which may be difficult to understand and less relevant to the current situation of the adolescent and young adult population (Gray \& Wilson, 2007; Hoyle et al., 2002; Primi et al., 2011). To overcome these three limitations, Hoyle et al. (2002) developed a short version of the SSS-V which they named the Brief Sensation-seeking Scale (BSSS). BSSS consists of 8 items which are divided into four domains, as in SSS-V. Examinations of the psychometric properties of BSSS conducted by Hoyle et al. showed convincing reliability and validity. The reliability test using the internal consistency method showed an alpha coefficient of 0.76 . The construct validity of the BSSS was carried out using the confirmatory factor analysis (CFA) method, which resulted in a single factor model specification (not four factors such as SSS-V) with a fairly good fitness index value, $\chi^{2}=621.46$, $\mathrm{CFI}=0.93$, RMSEA $=0.069(90 \%$ confidence interval $=0.065-0.074)$. These findings indicate that the BSSS has better psychometric properties than other short versions of sensation-seeking measures, such as the BSSS-4 (four items; Stephenson et al., 2003) and the 2-item sensation-seeking scale (Slater, 2003).

The BSSS has also been widely adapted into several languages and cultures. Various tests of the validity of the BSSS adaptation have been carried out, including in Chinese (Chen et al., 2013), Italian (Primi et al., 2011), Peruvian (Merino-Soto \& Salas Blas, 2017; Saletti et al., 2017), Dutch (van Dongen 
et al., 2021), Spanish (Martín-Fernández et al., 2021), French (Belley-Ranger et al., 2021), and Portuguese (Sousa et al., 2021) cultures. Validity and reliability of the adaptation of the BSSS showed satisfactory results (see Table 1 for the complete results of each language adaptation). One of the interesting findings from the results of these adaptations is the number of factors found to be the most fit. Some (e.g. Martín-Fernández et al., 2021; Primi et al., 2011) found that the best fit model consisted of a single factor (unidimensional) like the original BSSS model (Hoyle et al., 2002), while other findings (e.g. Chen et al., 2013; Sousa et al., 2021) showed the 4-factor model as the fittest model, as in the SSS-V measuring instrument (Zuckerman et al., 1978). This difference indicates that there are variations in the fitness of the model that may be relevant to each culture. That is, the accuracy of measurements in one culture is not necessarily comparable to the accuracy of measurements in different cultures.

Studies on the sensation-seeking construct not only focus on its relationship to risky behaviors but also its relationship to several other personality traits (de Vries et al., 2009; Zuckerman \& Glicksohn, 2016) and also its relationship to demographic factors, such as age and gender (Ball et al., 1984; Cross et al., 2013). Regarding other personality traits, previous studies have found that sensation-seeking is correlated with the Big Five personality dimensions. Specifically, sensation-seeking was found to be positively correlated with the openness dimension and negatively correlated with conscientiousness and agreeableness (Aluja et al., 2003; Dahlen \& White, 2006; Rumbold et al., 2021; Vries et al., 2009). Demographically, most of the literature found that men showed higher sensation-seeking than women, as well as a negative correlation between sensation-seeking and age (Ball et al., 1984; Cross et al., 2013; Roth et al., 2005, 2007).

Although previous research has shown that the BSSS is a valid and reliable sensation-seeking measurement instrument in various cultures and languages, the psychometric properties of BSSS in Indonesian are not yet known. Thus, the first objective of the present study was to further validate the BSSS by testing the psychometric properties of the Indonesian version of the BSSS on a general sample. The author assumes that the Indonesian version of the BSSS will show good psychometric properties as has been found in other languages. Second, considering that there are different findings regarding the number of structural factors that fit (1-factor vs. 4-factor) in the BSSS in tests in several countries, the present study also aims to examine how many factors are more fit in the Indonesian sample.

Construct validity testing was also carried out by correlating the Indonesian version of the BSSS score (BSSS-I) with other personality trait measurement scores, namely agreeableness, conscientiousness, and openness to experience. It is expected that the higher the participant's BSSS-I score, the higher the openness to experience score (convergent), whereas the agreeableness and conscientiousness scores will be lower (discriminant). In addition, the validity of the criteria was also tested by comparing the BSSS-I score with demographic factors, i.e., age and gender. Finally, testing the validity of the concurrent criteria was carried out by regressing the BSSS-I score against the risky behavior score, in this case, risky driving behavior. Meanwhile, reliability testing was carried out using the internal consistency method through Cronbach's alpha coefficient. It is expected that the Indonesian version of the BSSS has a Cronbach alpha coefficient with a moderate-high level $(\alpha>0.7)$. 
JP3I (Jurnal Pengukuran Psikologi dan Pendidikan Indonesia), I0(2), 2021

Table 1. Comparison of BSSS Factor Structures Across Countries/Cultures

\begin{tabular}{|c|c|c|c|c|c|}
\hline Cultures & Authors & $\begin{array}{c}\text { Factor } \\
\text { Numbers }\end{array}$ & Reliability & $\begin{array}{l}\text { Validation } \\
\text { Methods }\end{array}$ & Results \\
\hline USA & $\begin{array}{l}\text { Hoyle et al. } \\
(2002)\end{array}$ & 1 & $\alpha=0.76$ & CFA & $\begin{array}{l}\chi^{2}=621.46 ; \\
\text { CFI }=0.93 ; \\
\text { RMSEA }=0.07\end{array}$ \\
\hline Italy & $\begin{array}{l}\text { Primi et al. } \\
\text { (2011) }\end{array}$ & 1 & $\alpha=0.73$ & CFA & $\begin{array}{l}\chi^{2}=67.20 ; \\
\text { CFI }=0.95 ; \\
\text { RMSEA }=0.05\end{array}$ \\
\hline China & $\begin{array}{l}\text { Chen et al. } \\
\text { (2013) }\end{array}$ & 4 & $\alpha=0.90$ & CFA & $\begin{array}{l}\chi^{2}=30.8 \\
\text { CFI=0.98; } \\
\text { SRMR }=0.03\end{array}$ \\
\hline Peru & $\begin{array}{l}\text { Saletti et al } \\
\text { (2017) }\end{array}$ & 1 & $\alpha=0.82$ & CFA & $\begin{array}{l}\chi^{2}=56.74 \\
\text { CFI }=0.98 \\
\text { RMSEA }=0.05\end{array}$ \\
\hline Netherlands & $\begin{array}{l}\text { van Dongen et } \\
\text { al. (2021) }\end{array}$ & 4 & $\alpha=0.75$ & criterion & $\begin{array}{l}r=0.56^{*} \\
(\text { TriPM); } \\
r=0.42^{*} \text { (BIS-11) }\end{array}$ \\
\hline Portugal & $\begin{array}{l}\text { Sousa et al. } \\
(2021)\end{array}$ & 4 & $\alpha=0.80$ & CFA & $\begin{array}{l}\chi^{2}=51.46 \\
\text { CFI }=0,97 \\
\text { RMSEA }=0.07\end{array}$ \\
\hline Spain & $\begin{array}{l}\text { Martín- } \\
\text { Fernández et al., } \\
\text { (2021) }\end{array}$ & 1 & $\alpha=0.89$ & CFA & $\begin{array}{l}\chi^{2}=74.68 \\
\mathrm{CFI}=0.97 \\
\mathrm{RMSEA}=0.07\end{array}$ \\
\hline France & $\begin{array}{l}\text { Belley-Ranger et } \\
\text { al. (2021) }\end{array}$ & 1 & $\alpha=0.75$ & criterion & $r=0.75^{*}($ TriPM $)$ \\
\hline
\end{tabular}

Note: ${ }^{*} p<0.05$

\section{Methods}

\section{Participants}

The sample in this study consisted of 360 participants, aged 18-57 years old $(M=25.29, \mathrm{SD}=7.58)$ who live in Greater Jakarta. The composition of participants in terms of gender showed that most $(\mathrm{N}=195$, $54.2 \%)$ were women and the rest were men $(\mathrm{N}=165,45.8 \%)$. All participants were car drivers, with varying driving experience, ranging from 1 to 39 years $(\mathrm{M}=8.56, \mathrm{SD}=6.27)$.

\section{Instrument}

Brief Sensation-seeking Scale Indonesia (BSSS-I). BSSS-I is the result of adaptation (the process will be explained in the Procedure subsection) of the BSSS (Hoyle et al., 2002). The BSSS itself consists of eight items that contain statements about several aspects of sensation-seeking. Participants were asked to rate the suitability of each statement using a 5 -point Likert scale $(1=$ Strongly disagree, $5=$ Strongly agree $)$. A high score indicates a person's greater propensity to seek out activities or exhibit thrill-seeking behavior.

Ten Item Personality Inventory Indonesia (TIPI Indonesia). The measurement of personality traits agreeableness, openness to experience, and conscientiousness from the Big Five approach was carried out using the Indonesian TIPI (Akhtar, 2018), which was adapted from TIPI (Gosling et al., 2003). TIPI Indonesia consists of 10 items in measuring the five dimensions of the Big five personalities where 
each dimension is measured through two items, using a Likert scale with a range of 1 (Very untrue of me) to 5 (Very true of me). The reliability analysis in the present study shows that TIPI Indonesia has a reliability of $0.67,0.74$, and 0.61 for agreeableness, openness to experience, and conscientiousness, respectively.

Risk driving behavior scale (Bagaskara, 2017). This scale consists of 17 items that contain behaviors that are considered to increase the risk of accidents or endanger road users. The behaviors included in this scale are adaptations of the Risky Driving Behavior scale developed by Rhodes and Pivik (2011). This scale uses a 5-point Likert scale with a score ranging from 1 (never) to 5 (always). A high score indicates that participants are drivers who often exhibit risky behavior when driving. The reliability of this measuring instrument in this study shows a coefficient of 0.91 , which means it has high reliability.

The demographic data section contains several questions regarding participants personal data. This section includes questions regarding age, gender, domicile, driving experience.

\section{Procedure}

The BSSS adaptation process begins with the translation stage using forward and backward translation methods. Based on the process of adapting BSSS to Chinese culture conducted by Chen et al., (2013), the author adds one item ("I will do anything as long as it is exciting and stimulating") as an alternative to the item on the original scale ("I like wild parties"). This aims to see which of the two items is better understood by the participants and relevant to the Indonesian culture. The original BSSS items were translated from English into Indonesian by two Indonesian Psychologists who have excellent English proficiency. The translation process was carried out as is, without further adjustments to the items in the original language. This was done to see if the original translated items could be understood well by the participants. The results of the translations of the two people were then compared and further examined whether there were any essential differences between the two. The results of the translation of the two experts did not show a striking difference, so the researchers carried out the next stage, namely retranslating the translation into English (backward translation). This process involves two English experts. The results of the reverse translation were found to be similar, there were no essential differences.

After the translation process, the next step was to test the readability of the translation results. This trial involved 20 participants who had similar criteria to the target study participants. The test results showed that there was one item that needed a total revision, namely item 8 ("I like wild parties"). Most of the trial participants admitted that they had difficulty understanding this item and some stated that "wild parties" were not a common practice in Indonesia. The same thing was also found by Chen et al. (2013) in his research on Chinese culture. Meanwhile, the alternative item "I like exciting activities" adapted from Chen et al. (2013) is more understandable to the trial participants. Therefore, the author decided to use the item and not to use the translation of the original BSSS item that was previously mentioned. The complete list of translated items can be seen in Table 2.

Data collection was completed online using the Google Form platform. Links to questionnaires were provided through several channels, such as social media (Facebook) and messenger applications (Whatsapp and Telegram). At the beginning of the questionnaire, there is a research information section and a consent form for participating which contains the rights and risks of being involved in the research. Prospective participants who meet the criteria written in the information section can only access the scale of the study if they have agreed to the rights and risks as participants and provide a statement agreeing to participate.

Table 2. List of BSSS Items and Their Adaptation into Indonesian 
JP3I (Jurnal Pengukuran Psikologi dan Pendidikan Indonesia), I0(2), 202 I

\begin{tabular}{|c|c|c|c|}
\hline Item & Subscale & BSSS & BSSS Indonesia (BSSS-I) \\
\hline 1 & Experience seeking & $\begin{array}{l}\text { I would like to explore strange } \\
\text { places }\end{array}$ & $\begin{array}{l}\text { Saya ingin mengunjungi berbagai } \\
\text { tempat-tempat yang asing }\end{array}$ \\
\hline 2 & Boredom susceptibility & $\begin{array}{l}\text { I get restless when I spend too } \\
\text { much time at home }\end{array}$ & $\begin{array}{l}\text { Saya merasa gelisah bila terlalu lama di } \\
\text { rumah }\end{array}$ \\
\hline 3 & $\begin{array}{l}\text { Thrill \& adventure } \\
\text { seeking }\end{array}$ & I like to do frightening things & $\begin{array}{l}\text { Saya senang melakukan hal-hal yang } \\
\text { mengerikan }\end{array}$ \\
\hline 4 & Experience seeking & $\begin{array}{l}\text { I would like to take off on a } \\
\text { trip with no pre-planned routes } \\
\text { or timetables }\end{array}$ & $\begin{array}{l}\text { Saya ingin melakukan perjalanan yang } \\
\text { spontan, tanpa rute atau kegiatan yang } \\
\text { direncanakan sebelumnya }\end{array}$ \\
\hline 5 & Boredom susceptibility & $\begin{array}{l}\text { I prefer friends who are } \\
\text { excitingly unpredictable }\end{array}$ & $\begin{array}{l}\text { Saya lebih suka berteman dengan orang- } \\
\text { orang yang pemikirannya tidak dapat } \\
\text { ditebak }\end{array}$ \\
\hline 6 & $\begin{array}{l}\text { Thrill \& adventure } \\
\text { seeking }\end{array}$ & $\begin{array}{l}\text { I would like to try bungee } \\
\text { jumping }\end{array}$ & $\begin{array}{l}\text { Saya ingin mencoba bungee jumping, } \\
\text { terjun payung, atau aktivitas-aktivitas } \\
\text { menantang lainnya }\end{array}$ \\
\hline 7 & Disinhibition & $\begin{array}{l}\text { I would love to have new and } \\
\text { exciting experiences, even if } \\
\text { they are illegal }\end{array}$ & $\begin{array}{l}\text { Saya sangat ingin mempunyai } \\
\text { pengalaman yang baru dan } \\
\text { menyenangkan, walaupun itu } \\
\text { melanggar peraturan }\end{array}$ \\
\hline 8 & Disinhibition & $\begin{array}{l}\text { I will do anything as long as it } \\
\text { is exciting and stimulating* }\end{array}$ & $\begin{array}{l}\text { Saya menyukai kegiatan-kegiatan yang } \\
\text { membangkitkan gairah }\end{array}$ \\
\hline
\end{tabular}

Note: *adapted from BSSS-C (Chen et al., 2013)

\section{Data Analysis}

Descriptive statistics are used to analyze the mean and standard deviation of each item of the Indonesian BSSS of the present study. Scale reliability was analyzed using Cronbach's alpha internal consistency method and item-total correlation. The examination of the validity of the Indonesian BSSS factor structure is carried out through confirmatory factor analysis (CFA) with the maximum likelihood estimation method. To test the fitness of the model, the Comparative Fit Index (CFI), Tucker-Lewis Index (TLI), Root Mean Square Error of Approximation (RMSEA), and Standardized Root Mean Square Residual (SRMR) are used. CFI and TLI values of 0.95 indicate a very good level of accuracy; RMSEA and SRMS values of 0.6 indicate good accuracy, while RMSEA of 0.8 indicates poor accuracy (Hu \& Bentler, 1999). CFA analysis was carried out on two measurement models, namely the 1 -factor model (Hoyle et al., 2002; Martín-Fernández et al., 2021; Primi et al., 2011) and the 4-factor (Chen et al., 2013; Sousa et al., 2021; van Dongen et al., 2021). Validity was also analyzed based on the correlation analysis between Indonesia's BSSS score and personality traits agreeableness, openness to experience, and conscientiousness, as well as risky driving behavior and demographics (ie, age and gender). Hypothesis testing uses a significance level of 0.05 . All statistical analyzes were performed using Jamovi software version 1.8 (2021). 
JP3I (Jurnal Pengukuran Psikologi dan Pendidikan Indonesia), I0(2), 202 I

\section{Results and Discussion}

\section{Results}

\section{Descriptive and Reliability Analysis}

The descriptive statistics of each item and the corrected item-total correlation are shown in Table 3. The mean value of the BSSS-I score was 3.11 with $S D=0.74$, indicating that participants tended to show moderate preference in each item, except for item 1 which the average is quite high $(M=4.26)$. The skewness and kurtosis of each item can also be said to below. Corrected item-total correlation showed an intermediate coefficient $(r=0.31-0.63)$. In general, the internal consistency of the scale is acceptable $(\alpha=0.79)$.

Table 3. Descriptive Statistics of BSSS-I items

\begin{tabular}{ccccccccc}
\hline Item & Mean & $\boldsymbol{S D}$ & Min. & Max. & $\begin{array}{c}\text { Skewness } \\
(\mathbf{S E = 0 , 1 3 )}\end{array}$ & $\begin{array}{c}\text { Kurtosis } \\
(\mathbf{S E}=\mathbf{0 , 2 6})\end{array}$ & $\begin{array}{c}\text { Item-total } \\
\text { correlation }\end{array}$ & $\begin{array}{c}\boldsymbol{\alpha} \text { if item } \\
\text { deleted }\end{array}$ \\
\hline 1 & 4.26 & 0.81 & 1 & 5 & -1.11 & 1.31 & 0.31 & 0.79 \\
2 & 3.01 & 1.19 & 1 & 5 & 0.15 & -0.98 & 0.36 & 0.78 \\
3 & 2.66 & 1.13 & 1 & 5 & 0.14 & -0.77 & 0.57 & 0.75 \\
4 & 3.37 & 1.29 & 1 & 5 & -0.35 & -0.99 & 0.59 & 0.74 \\
5 & 3.00 & 1.08 & 1 & 5 & 0.06 & -0.56 & 0.58 & 0.75 \\
6 & 3.45 & 1.32 & 1 & 5 & -0.57 & -0.84 & 0.46 & 0.77 \\
7 & 2.61 & 1.29 & 1 & 5 & 0.30 & -1.04 & 0.63 & 0.74 \\
8 & 2.53 & 1.14 & 1 & 5 & 0.36 & -0.74 & 0.43 & 0.77 \\
Total & 21.88 & 5.21 & 10 & 35 & -0.03 & -0.46 & & \\
\hline
\end{tabular}

\section{Confirmatory Factor Analysis}

Confirmatory factor analysis (CFA) with the maximum likelihood estimation method was carried out on the two models tested, namely the 1-factor model and the 4-factor model (Table 4). The results of the analysis show that the 1 -factor model has an unsatisfactory accuracy value, CFI and TLI $<0.9$, and RMSEA > 0.6. Meanwhile, the 4-factor model shows a satisfactory level of accuracy with CFI and TLI $>0.9$, and RMSEA and SRMS 0.6. In conclusion, the 4-factor model was found to have better accuracy than the 1-factor model.

\section{Convergent and Discriminant Validity}

For the analysis of convergent validity, a Pearson correlation test was conducted between the BSSSI scores (both total scores and scores for each subscale) and the personality trait dimensions of openness experience. The results of the analysis showed a positive and significant correlation between the total score of BSSS-I and openness to experience $(r=0.14, p<0.05)$. For subscale analysis, the personality trait of openness to experience was significantly positively correlated with Experience seeking $(r=0.13, p<0.05)$ and Boredom susceptibility $(r=0.14, p<0.05)$. This indicates that individuals with high openness to experience tend to be more active in seeking new experiences and are prone to boring activities. Meanwhile, there was no significant correlation between openness to experience and Thrill-seeking subscales $(r=0.07$, $p=0.17)$ and Disinhibition $(r=0.09, p=0.07)$. 
JP3I (Jurnal Pengukuran Psikologi dan Pendidikan Indonesia), I0(2), 202 I

Table 4. Goodness of fit indices of the BSSS-I

\begin{tabular}{cccccccc}
\hline Model & $\chi^{2}$ & Df & CFI & TLI & RMSEA [90\% CI] & SRMR & Conclusion \\
\hline 1-factor & 82.94 & 14 & 0.88 & 0.82 & $0.1[0.09-0.14]$ & 0.05 & Not fit \\
4-factor & 33.90 & 14 & 0.97 & 0.95 & $0.06[0.04-0.09]$ & 0.03 & Fit \\
\hline
\end{tabular}

For discriminant validity analysis, a significant negative correlation was found between the BSSS-I score and the personality traits agreeableness $(r=0.20, p<0.05)$ and conscientiousness $(r=0.15, p<0.05)$. Correlation analysis of each BSSS-I subscale with other personality trait variables showed more mixed results. The agreeableness personality trait was found to be significantly negatively correlated with the Thrill-seeking subscales $(r=-0.14, p<0.05)$, Boredom susceptibility $(r=-0.23, p<0.05)$, and Disinhibition ( $r=-0.15, p<0.05)$, but not significant with experience seeking $(r=-0.08, p=0.14)$. Meanwhile, the conscientiousness personality trait was found to be significantly negatively correlated with the Experience seeking subscales $(r=-0.11, p<0.05)$, Boredom susceptibility $(r=-0.11, p<0.05)$, and Disinhibition $(r=-$ $0.18, p<0.05)$, but not significant with Thrill-seeking $(r=-0.06, p=0.29)$. The results of the correlation analysis between variables can be seen in Table 5 .

Table 5. Correlation Matrix

\begin{tabular}{lccccc}
\hline & BSSS-I & BSSS-I T & BSSS-I-E & BSSS-I B & BSSS-I D \\
\hline Agreeableness & -0.19 & -0.14 & -0.08 & -0.23 & -0.15 \\
Conscientiousness & -0.15 & -0.06 & -0.11 & -0.11 & -0.18 \\
Openness & 0.14 & 0.07 & 0.13 & 0.14 & 0.09 \\
Age & -0.39 & -0.30 & -0.27 & -0.30 & -0.33 \\
RDB & 0.34 & 0.29 & 0.20 & 0.23 & 0.30 \\
\hline
\end{tabular}

Notes: BSSS-I = Brief Sensation-seeking Scale Indonesian version; BSSS-I T = Thrill-seeking; BSSS-I E = Experience seeking; BSSS-I B = Boredom susceptibility; BSSS-I D = Disinhibition; $\mathrm{RDB}=$ Risky driving behavior; the correlation coefficient in bold indicates the significance of $\mathrm{p}<0.05$

\section{Construct Validity}

The construct validity test of BSSS-I was carried out by comparing the average total score of BSSS-I and each sub-scale based on gender and age group. In terms of gender, as expected, male participants showed higher BSSS-I scores than women, both in total score (23.03 vs. 20.91, $t=3.92, p<0.05, d=0.41$ ), as well as on each subscale (Thrill-seeking: 6.64 vs. $5.65, t=4.61, p<0.05, d=0.49$; Boredom susceptibility: 6.24 vs. $5.82, t=2.20, p<0.05, d=0.23$; Disinhibition: 5.53 vs. $4.80, t=3.20, p<0.05, d=0.34$ ), except for the Experience seeking subscale ( 7.76 vs. $7.52, t=1.28, p=0.20$ ).

In terms of age, it was generally found that the BSSS-I scores, both total and each subscale, were significantly negatively correlated with age (see Table 5). This indicates that the level of sensation-seeking will decline with age. Next, the age was categorized into three groups, namely 18 -24 years $(N=235), 25$ 39 years $(N=101)$, and $>39$ years $(N=24)$. Categorization was done to see a comparison of the sensationseeking level of each group. The ANOVA result showed a significant difference between the three age groups, $F(3.357)=34.13, p<0.05$. The post-hoc test using the Tukey correction method showed that the 18-24-year age group $(M=23.23, S D=4.95)$ had a higher level of sensation-seeking than the 25-39-year age group $(M=20.05, S D=4.61, p<0.05)$, as well as the $>39$ year age group $(M=16.61, S D=4.16, p<$ 0.05 ). In addition, the level of sensation-seeking in the 25 to 39 -year age group was significantly higher than the $>39$-year age group $(p<0.05)$. ANOVA was also performed on the scores of each subscale. The results show a pattern similar to that found in the analysis of the BSSS-I total score (see Table 6). 


\section{Concurrent Validity}

Concurrent validity was carried out by performing multiple linear regression analysis with sensationseeking, agreeableness trait, openness to experience, and conscientiousness as predictor variables and risky driving behavior as an outcome variable. The results of the analysis showed that the four predictor variables were able to explain $23 \%$ of the variance of risky driving behavior scores, $(F(4,355)=26.39, p<0.05)$ of risky driving behavior, where BSSS-I had the largest contribution among other predictor variables $(\beta=0.27$; $t(355)=5.46, p<0.05$ ) (see Table 7). Multiple linear regression was performed again, this time placing the four BSSS-I subscales and the three Big Five personality trait dimensions as predictors. The results of the analysis show that only Thrill-seeking and Disinhibition subscales have a significant contribution in predicting risky driving behavior $(\beta=0.15 ; t(352)=2.75, p<0.05 ; \beta=0.14 ; t(352)=2.49, p<0.05$, respectively), while the Experience seeking and Boredom susceptibility subscales did not show a significant contribution.

\section{Discussion}

The purpose of this study is to test the validity and reliability of the BSSS-I, which is an adaptation of the BSSS developed by Hoyle et al. (2002), to obtain an efficient measurement of trait sensation-seeking to be used in the context of research in Indonesia. The results generally describe that BSSS-I has satisfactory psychometric properties (validity and reliability).

In terms of reliability, it was found that BSSS-I showed a very good level of reliability $(\alpha=0.79)$. This level of reliability is higher than that found by many BSSS-I adaptation studies in other countries (Primi et al. (2011) in Italy, van Dongen et al. (2021) in the Netherlands, and Belley-Ranger et al. (2021) in France), even when compared with the initial BSSS study by Hoyle et al. (2002). Item analysis using the corrected item-total correlation method also showed good consistency between each item score and the total score $(r=0.31-0.63)$.

The CFA analysis to examine the BSSS-I factor structure shows that this scale is more suitable for the 4-factor model than the 1-factor model. Based on some fitness indices used as criteria, the 4-factor BSSS-I showed a higher level of fitness $(\mathrm{CFI}=0.97)$ compared to what was found in the 1-factor BSSS model, both in the original study (CFI $=0.93$ ) (Hoyle et al., 2002) as well as on adaptation in Italy $(C F I=0.95)$ (Primi et al., 2011). The results of this study are in line with those found by Chen et al. (2013) in China and Sousa et al. (2021) in Portugal, both in terms of the number of factors and the degree of fitness.

Convergent validity test shows that BSSS-I is positively correlated with the openness to experience trait. This finding is in line with some previous studies which found a similar relationship between the two variables (Aluja et al., 2003; de Vries et al., 2009). The BSSS-I discriminant validity test also showed promising findings. The BSSS-I score was found to be negatively correlated with the agreeableness and conscientiousness traits. These results are in line with several previous studies (Dahlen \& White, 2006; Rumbold et al., 2021; Vries et al., 2009). More specifically, agreeableness is negatively correlated with the three BSSS-I subscales, except for Experience seeking. Furthermore, conscientiousness has a negative correlation with the Boredom susceptibility, Experience seeking, and Disinhibition subscales, but not with Thrill-seeking, similar to what was found by Dahlen \& White (2006) and Rumbold et al. (2021). 
JP3I (Jurnal Pengukuran Psikologi dan Pendidikan Indonesia), I0(2), 202 I

Table 6. BSSS-I Mean Differences Based on Age Group

\begin{tabular}{lcccccc}
\hline & Age group & $\boldsymbol{N}$ & Mean & $\boldsymbol{S D}$ & $\boldsymbol{S E}$ & $\boldsymbol{F}$ \\
\hline BSSS-I & 18-24 years & 235 & 23.23 & 4.95 & 0.32 & 30.25 \\
& 26-39 years & 101 & 20.05 & 4.61 & 0.46 & \\
Thrill-seeking & >39 years & 23 & 16.61 & 4.16 & 0.87 & \\
& 18-24 years & 235 & 6.48 & 2.07 & 0.13 & 14.74 \\
& 26-39 years & 101 & 5.67 & 1.86 & 0.19 & \\
Experience seeking & >39 years & 23 & 4.39 & 2,02 & 0.42 & \\
& 18-24 years & 235 & 7.93 & 1.60 & 0.10 & 13.57 \\
Boredom susceptibility & 26-39 years & 101 & 7.25 & 1.85 & 0.18 & \\
& >39 years & 23 & 6.30 & 1.72 & 0.36 & \\
& 18-24 years & 235 & 6.40 & 1.74 & 0.11 & 19.88 \\
Disinhibition & 26-39 years & 101 & 5.50 & 1,84 & 0.18 & \\
& >39 years & 23 & 4.39 & 1.50 & 0.31 & \\
& 18-24 years & 235 & 5.67 & 2.21 & 0.14 & 24.20 \\
& 26-39 years & 101 & 4.28 & 1.73 & 0.17 & \\
\hline
\end{tabular}

Note: all $F$ statistics show significance $p<0,05$

The construct validity test was also carried out by looking at the differences in the BSSS-I scores based on gender and age. The results of the independent samples t-test analysis showed that in general, men showed a higher level of sensation-seeking than women. This finding is in line with some previous studies. More specifically, gender-based differences were also found in all BSSS-I subscales, except for the Experience seeking subscale. Non-significant sex differences on this subscale were also found in previous studies (Kurtz \& Zuckerman, 1978; Rahmani \& Lavasani, 2012; Wolfgang, 1988). This indicates that men and women do not have different preferences in the tendency to seek new experiences.

In terms of age, it was found that the lower age group tended to show higher levels of sensation-seeking in general. The same thing was also found in each BSSS-I subscale score. This finding indicates that a person's tendency to seek sensation decreases with age. However, this conclusion needs to be understood carefully considering that the items on this measuring instrument are considered to describe behaviors that are more relevant to the younger age group (e.g., bungee jumping, spontaneous travel), so it is natural that the younger age group tends to show higher preference than older age groups (Arnett, 1994).

Finally, concurrent validity testing showed that the BSSS-I score was the strongest predictor among other personality trait scores tested in this study. These results support some previous findings that reveal a fairly large role of trait sensation-seeking on the emergence of risky driving behavior (Bagaskara, 2017; Dahlen et al., 2005; Dahlen \& White, 2006; Taubman - Ben-Ari et al., 2016). In terms of subscales, only Thrill-seeking and Disinhibition subscales have a significant contribution in predicting risky driving behavior. This is understandable considering that the two subscales are quite closely related to sensationseeking through risky behavior, while the other two subscales are not directly related to risk-taking. The results of this subscale analysis complement several previous findings, which mostly use the total score from the sensation-seeking measurement, either using SSS-V or BSSS. This more specific approach allows future researchers to focus more on certain dimensions of sensation-seeking in understanding relevant risk behaviors. 
JP3I (Jurnal Pengukuran Psikologi dan Pendidikan Indonesia), I0(2), 2021

Table 7. Multiple Regression Analysis with Risky Driving Behavior as Outcome Variable

\begin{tabular}{lcccc}
\hline Predictors & $\boldsymbol{\beta}$ & Std. error & $\boldsymbol{t}$ & $\boldsymbol{p}$ \\
\hline BSSS-I & 0.27 & 0.10 & 5.46 & $<.001$ \\
Agreeableness & -0.25 & 0.81 & -4.89 & $<.001$ \\
Conscientiousness & -0.16 & 0.84 & -2.94 & 0.004 \\
Openness & -0.02 & 0.75 & -0.32 & 0.749 \\
$R^{2}=0.23, p<0.05$ & & & & \\
& & & & \\
Thrill-seeking & 0.15 & 0.57 & 2.75 & 0.006 \\
Experience seeking & 0.04 & 0.72 & 0.65 & 0.513 \\
Boredom susceptibility & 0.03 & 0.69 & 0.46 & 0.645 \\
Disinhibition & 0.14 & 0.54 & 2.49 & 0.013 \\
Agreeableness & -0.25 & 0.82 & -4.83 & $<.001$ \\
Conscientiousness & -0.16 & 0.86 & -2.91 & 0.004 \\
Openness & -0.01 & 0.76 & -0.23 & 0.819 \\
$R^{2}=0.24, p<0.05$ & & & & \\
\hline
\end{tabular}

There are some limitations in this study. First, the research was conducted using a cross-sectional method, so the results found cannot describe the extent to which sensation-seeking is a persistent trait. Therefore, longitudinal research needs to be done to overcome this limitation. Second, this study involved samples from age groups whose ranges were quite large, so they were unable to explain sensation-seeking symptoms that were more specific to certain age groups. Third, test-retest reliability testing may help to explain the stability of the measuring instrument across time. Finally, further research needs to involve measuring other risk behaviors, such as risky sexual behavior, marijuana use, gambling behavior, and involvement in risky sports. These measurements can be the criteria that can complement the concurrent validity testing of the BSSS-I so that it will produce more comprehensive findings.

\section{Conclusion}

The adaptation of the BSSS into the Indonesian socio-cultural context carried out in this study shows that the BSSS-I can be a valid and reliable instrument for measuring trait sensation-seeking. More specifically, the 4-factor BSSS-I model shows a more adequate model than the 1-factor model. With a relatively small number of items, it allows BSSS-I to be used more widely in research on risky behavior. Future research can use the BSSS-I to evaluate its efficacy as a screening instrument for maladaptive personality problems related to risk-taking tendencies.

\section{References}

Akhtar, H. (2018). Translation and validation of the ten-item personality inventory (TIPI) into Bahasa Indonesia. International Journal of Research Studies in Psychology, 7(2), 59-69. https://doi.org/10.5861/ijrsp.2018.3009

Aluja, A., García, Ó., \& García, L. F. (2003). Relationships among extraversion, openness to experience, and sensation-seeking. Personality and Individual Differences, 35(3), 671-680. https://doi.org/10.1016/S0191-8869(02)00244-1

Arnett, J. (1994). Sensation-seeking: A new conceptualization and a new scale. Personality and Individual Differences, 16(2), 289-296. https://doi.org/10.1016/0191-8869(94)90165-1

Bagaskara, S. (2017). Perbandingan perilaku mengemudi berisiko antara pengemudi mobil dan pengendara sepeda motor dan kaitannya dengan faktor-faktor kepribadian. Jurnal Transportasi, 
JP3I (Jurnal Pengukuran Psikologi dan Pendidikan Indonesia), I0(2), 2021

17(2), 79-88.

Ball, I. L., Farnill, D., \& Wangeman, J. F. (1984). Sex and age differences in sensation-seeking: Some national comparisons. British Journal of Psychology, 75(2), 257-265. https://doi.org/10.1111/j.20448295.1984.tb01897.x

Baretta, D., Greco, A., \& Steca, P. (2017). Understanding performance in risky sport: The role of selfefficacy beliefs and sensation-seeking in competitive freediving. Personality and Individual Differences, 117, 161-165. https://doi.org/10.1016/j.paid.2017.06.006

Belley-Ranger, E., Carbonneau, H., \& Trudeau, F. (2021). Psychometric properties of the French version of Brief Sensation-seeking Scale (B-SSS). European Review of Applied Psychology, 71(3), 100655. https://doi.org/10.1016/j.erap.2021.100655

Charnigo, R., Noar, S. M., Garnett, C., Crosby, R., Palmgreen, P., \& Zimmerman, R. S. (2013). Sensation-seeking and Impulsivity: Combined Associations with Risky Sexual Behavior in a Large Sample of Young Adults. The Journal of Sex Research, 50(5), 480-488. https://doi.org/10.1080/00224499.2011.652264

Chen, X., Li, F., Nydegger, L., Gong, J., Ren, Y., Dinaj-Koci, V., Sun, H., \& Stanton, B. (2013). Brief Sensation-seeking Scale for Chinese - Cultural adaptation and psychometric assessment. Personality and Individual Differences, 54(5), 604-609. https://doi.org/10.1016/j.paid.2012.11.007

Cross, C. P., Cyrenne, D.-L. M., \& Brown, G. R. (2013). Sex differences in sensation-seeking: a metaanalysis. Scientific Reports, 3(1), 2486. https://doi.org/10.1038/srep02486

Dahlen, E. R., Martin, R. C., Dahlen, E. R., Martin, R. C., Ragan, K., \& Kuhlman, M. M. (2005). Driving anger, sensation-seeking, impulsiveness, and boredom proneness in the prediction of unsafe driving. June 2016. https://doi.org/10.1016/j.aap.2004.10.006

Dahlen, E. R., \& White, R. P. (2006). The Big Five factors, sensation-seeking, and driving anger in the prediction of unsafe driving. Personality and Individual Differences, 41(5), 903-915. https://doi.org/10.1016/j.paid.2006.03.016

Dunlop, S. M., \& Romer, D. (2010). Adolescent and Young Adult Crash Risk: Sensation-seeking, Substance Use Propensity and Substance Use Behaviors. Journal of Adolescent Health, 46(1), 90-92. https://doi.org/10.1016/j.jadohealth.2009.06.005

Dwiputri, M. N. (2015). Hubungan Konformitas, Kepercayaan Diri, Locus Of Control, Strategi Coping dan Sensation-seeking Terhadap Intensi Menggunakan Ganja. Psikoborneo: Jurnal Ilmiah Psikologi, $3(4)$.

Gosling, S. D., Rentfrow, P. J., \& Swann, W. B. (2003). A very brief measure of the Big-Five personality domains. Journal of Research in Personality, 37(6), 504-528. https://doi.org/10.1016/S00926566(03)00046-1

Gray, J. M., \& Wilson, M. A. (2007). A detailed analysis of the reliability and validity of the sensationseeking scale in a UK sample. Personality and Individual Differences, 42(4), 641-651. https://doi.org/10.1016/j.paid.2006.08.019

Hald, G. M., \& Mulya, T. W. (2013). Pornography consumption and non-marital sexual behavior in a sample of young Indonesian university students. Culture, Health \& Sexuality, 15(8), 981-996. https://doi.org/10.1080/13691058.2013.802013

Hidayah, N. Z., \& Izzaty, R. E. (2019). Influence of Peers' Conformity and Sensation-seeking towards Smoking Behavior on Adolescents. International Journal of Multicultural and Multireligious Understanding, 6(6), 103-115.

Horvath, P., \& Zuckerman, M. (1993). Sensation-seeking, risk appraisal, and risky behavior. Personality and Individual Differences, 14(1), 41-52. https://doi.org/10.1016/0191-8869(93)90173-z

Hoyle, R. H., Stephenson, M. T., Palmgreen, P., Pugzles, E., \& Donohew, R. L. (2002). Reliability and validity of a brief measure of sensation-seeking. 32, 401-414. 
Hu, L., \& Bentler, P. M. (1999). Cutoff criteria for fit indexes in covariance structure analysis: Conventional criteria versus new alternatives. Structural Equation Modeling: A Multidisciplinary Journal, 6(1), 1-55. https://doi.org/10.1080/10705519909540118

Islamiah, K., \& Supradewi, R. (2020). Kecenderungan Kecanduan Game Online Ditinjau dari Sensationseeking Trait pada Gamers Komunitas Game Online. Psisula: Prosiding Berkala Psikologi, 2(1), 114 123. https://doi.org/10.24036/jrp.v2020i1.8159

Kurtz, J. P., \& Zuckerman, M. (1978). Race and Sex Differences on the Sensation-seeking Scales. Psychological Reports, 43(2), 529-530. https://doi.org/10.2466/pr0.1978.43.2.529

Martín-Fernández, M., Marco, M., Romo, M., \& Moyano, M. (2021). Adaptation of the brief sensationseeking scale in Spanish young adults: Psychometric properties and validity evidence. Current Psychology, 40(6), 2698-2706. https://doi.org/10.1007/s12144-019-00190-4

Mehroof, M., \& Griffiths, M. D. (2010). Online Gaming Addiction: The Role of Sensation-seeking, SelfControl, Neuroticism, Aggression, State Anxiety, and Trait Anxiety. Cyberpsychology, Behavior, and Social Networking, 13(3), 313-316. https://doi.org/10.1089/cyber.2009.0229

Merino-Soto, C., \& Salas Blas, E. (2017). Brief Sensation-seeking Scale: Latent structure of 8-item and 4-item versions in Peruvian adolescents. Adicciones, 30(1), 41. https://doi.org/10.20882/adicciones.842

Pearson, M. R., Hustad, J. T. P., Neighbors, C., Conner, B. T., \& Bravo, A. J. (2018). Personality, marijuana norms, and marijuana outcomes among college students. Addictive Behaviors, 76, 291297. https://doi.org/10.1016/j.addbeh.2017.08.012

Primi, C., Narducci, R., Benedetti, D., Donati, M., \& Chiesi, F. (2011). Validity and reliability of the Italian version of the brief sensation-seeking scale (BSSS) and its invariance across age and gender. Testing, Psychometrics, Methodology in Applied Psychology, 18(4), 231-241.

Rahmani, S., \& Lavasani, M. G. (2012). Gender Differences in Five-Factor Model of Personality and Sensation-seeking. Procedia - Social and Behavioral Sciences, 46, 2906-2911. https://doi.org/10.1016/j.sbspro.2012.05.587

Ravert, R. D., Kim, S. Y., Schwartz, S. J., Weisskirch, R. S., Zamboanga, B. L., Ham, L. S., Donnellan, M. B., \& Bersamin, M. M. (2013). The Association Between Sensation-seeking and Well-Being Among College-Attending Emerging Adults. Journal of College Student Development, 54(1), 17-28. https://doi.org/10.1353/csd.2013.0004

Rhodes, N., \& Pivik, K. (2011). Age and gender differences in risky driving: The roles of positive affect and risk perception. Accident Analysis \& Prevention, 43(3), 923-931. https://doi.org/10.1016/j.aap.2010.11.015

Roberti, J. W. (2004). A review of behavioral and biological correlates of sensation-seeking. Journal of Research in Personality, 38(3), 256-279. https://doi.org/10.1016/S0092-6566(03)00067-9

Roth, M., Hammelstein, P., \& Brähler, E. (2007). Beyond a youthful behavior style - Age and sex differences in sensation-seeking based on need theory. Personality and Individual Differences, 43(7), 1839-1850. https://doi.org/10.1016/j.paid.2007.06.004

Roth, M., Schumacher, J., \& Brähler, E. (2005). Sensation-seeking in the community: Sex, age and sociodemographic comparisons on a representative German population sample. Personality and Individual Differences, 39(7), 1261-1271. https://doi.org/10.1016/j.paid.2005.05.003

Rumbold, J. L., Madigan, D. J., Murtagh-Cox, A., \& Jones, L. (2021). Examining profiles of the big five and sensation-seeking among competitive climbers. https://doi.org/10.1016/j.psychsport.2021.101951

Saletti, S. R., Chang, D. O., Pérez-Aranibar, C. C., \& Campos, F. O. (2017). Psychometric properties of the Brief Sensation-seeking Scale in Peruvian teenagers. Psicothema, 29(1), 133-138. https://doi.org/10.7334/psicothema2016.144

Slater, M. D. (2003). Alienation, Aggression, and Sensation-seeking as Predictors of Adolescent Use of Violent Film, Computer, and Website Content. Journal of Communication, 53(1), 105-121. 
https://doi.org/10.1111/j.1460-2466.2003.tb03008.x

Sousa, C., Gonçalves, G., Sousa, A., \& Pinto, E. (2021). An assessment of the psychometric properties of the Brief Sensation-seeking Scale and its prediction in safety performance in a Portuguese adult sample. Current Psychology, 40(2), 497-509. https://doi.org/10.1007/s12144-018-9966-8

Stephenson, M. T., Hoyle, R. H., Palmgreen, P., \& Slater, M. D. (2003). Brief measures of sensationseeking for screening and large-scale surveys. Drug and Alcohol Dependence, 72(3), 279-286. https://doi.org/10.1016/j.drugalcdep.2003.08.003

Taubman - Ben-Ari, O., Eherenfreund - Hager, A., \& Prato, C. G. (2016). The value of self-report measures as indicators of driving behaviors among young drivers. Transportation Research Part F: Traffic Psychology and Behaviour, 39, 33-42. https://doi.org/10.1016/j.trf.2016.03.005

The jamovi Project. (2021). jamovi (ver. 1.8). https://www.jamovi.org

van Dongen, J. D. M., de Groot, M., Rassin, E., Hoyle, R. H., \& Franken, I. H. A. (2021). Sensationseeking and its relationship with psychopathic traits, impulsivity and aggression: a validation of the Dutch Brief Sensation-seeking Scale (BSSS). Psychiatry, Psychology and Law, 27(1), 1-13. https://doi.org/10.1080/13218719.2020.1821825

Vries, R. E. de, Vries, A. de, \& Feij, J. A. (2009). Sensation-seeking, risk-taking, and the HEXACO model of personality. Personality and Individual Differences, 47(6), 536-540. https://doi.org/10.1016/j.paid.2009.05.029

Wolfgang, A. K. (1988). Gambling as a function of gender and Sensation-seeking. Journal of Gambling Behavior, 4(2), 71-77. https://doi.org/10.1007/BF01020103

Zuckerman, M. (2007). The sensation-seeking scale V (SSS-V): Still reliable and valid. Personality and Individual Differences, 43(5), 1303-1305. https://doi.org/10.1016/j.paid.2007.03.021

Zuckerman, M. (2009). Sensation-seeking, in M. R. Leary \& R. H. Hoyle (Ed.), Handbook of Individual Differences in Social Behavior (page. 455-465). The Guilford Press.

Zuckerman, M., Eysenck, S. B., \& Eysenck, H. J. (1978). Sensation-seeking in England and America: Cross-cultural, age, and sex comparisons. Journal of Consulting and Clinical Psychology, 46(1), 139149. https://doi.org/10.1037/0022-006X.46.1.139

Zuckerman, M., \& Glicksohn, J. (2016). Hans Eysenck's personality model and the constructs of sensation-seeking and impulsivity. Personality and Individual Differences, 103, 48-52. https://doi.org/10.1016/j.paid.2016.04.003

Zuckerman, M., \& Kuhlman, D. M. (2000). Personality and risk-taking: common biosocial factors. Journal of Personality, 68(6), 999-1029. https://doi.org/10.1111/1467-6494.00124 